bête (1946), Eugene Marner's Beauty and the Beast (1987), and Christophe Gans' La belle et la bête (2014).

Two papers were dedicated to the popular Harry Potter series: using the examples of J.K. Rowling's novels (and especially the Pottermore website) and Tolkien's The Lord of the Rings trilogy (and accompanying correspondence between Tolkien and readers curious to learn more about Middle-earth), Anahit Behrooz explored the notion of text as a mutable and continuously evolving entity, which the author and readers constantly rework with the help of paratextual and supplementary elements. Ekaitz Icazuriaga addressed the representation of gender in the first book in Rowling's series, Harry Potter and the Philosopher's Stone, by analysing the character of Hermione Granger.

In addition to participants' presentations, the two Conference days were filled to the brim with various other attractive events, such as the Conference dinner and closing ceremony, the "Horizontes de João Aguiar" exhibition, mounted in the FLUL Library, a meeting of the "Devoradores de livros" [Book Eaters] book club, a conversation with the award-winning Scottish sci-fi writer Ken MacLeod, author of the Fall Revolution series (1995-1999), and the Engines of Light (2000-2002) and The Corporation Wars (20162017) trilogies, and two keynotes.

The first keynote, Katherine Fowkes' "A Deal with the Devil? Zombies vs. Tricksters as Cinematic Magic" presented the lifeless zombie and the trickster who, as Fowkes explained, breathes new life into people and situations by creating mischief and chaos, as antipodes of sorts. The author then used the two figures as metaphors for films which, in their "zombie" forms, rely on stereotypes and "soul-less", clichéd stories. In contrast, "trickster" films (genres such as fantasy and sci-fi) re-ignite the audience's imagination, inviting them to view the world around them in a new light. In the second keynote, Andrew M. Butler analysed Alex Garland's 2015 sci-fi film Ex Machina, especially its intertextual links with the myth of Pygmalion and Charles Perrault's fairy tale "Bluebeard".

For the duration of the Conference, the FLUL building also housed another highly attractive event: a sci-fi and fantasy market, where aficionados could purchase a variety of pop-culture-themed items, such as movie posters, badges featuring famous TV characters, hand-knit Pokémon balls and Cthulhu toys fashioning charming bowler hats. Hopefully, they too will return in 2018, for the Messengers' fifth "episode".

Nada Kujundžić

\title{
The Child and the Book International Conference
}

Valencia, Spain, 30 March - 1 April 2017

DOI: 10.21066/carcl.libri.2017-06(01).0016

It seemed as if the 2016 Child and the Book Conference in Wrockaw had only just ended, but here we found ourselves at the Child and the Book again, this time in Valencia, at the Tarongers Campus of the University of Valencia. This year's topic was "Interdisciplinary Links between Children's Literature and the Arts", and the whole affair was interdisciplinary indeed: there were educators, linguists, literature scholars, film scholars, artists, and art historians, translation scholars and literacy experts; we talked about music, art, picturebooks, adaptations, illustrations, cognitive approaches, ekphrasis, education strategies, apps, and 
museums of various kinds, and discussed well-known classics and fresh publications, the old, the new, and the future. We sang, we ate, and we learned.

The first keynote was by the person who everyone always quotes, i.e. Perry Nodelman. It was titled "Touching Art: The Art Museum as a Picture Book, and the Picture Book as Art" and offered an interesting twist on looking at art in the context of children's literature: instead of looking at picturebooks as art, he made us look at art - and how it is arranged in museums - in the way we look at and read picturebooks. Then, the panel sessions began, and we all had to face the sweet and sour element of choice. The first two panels were "Adaptations, Intermediality, Trans-mediality, Cross-mediality" and "Animation and Films for Children and Young Adults". I chose the first, which seemed to be tailored especially to me and my own research: first, Erica Hateley talked about the traces of Edward Hopper in picturebooks, then Željka Flegar presented a cognitive analysis of words and images in The Chronicles of Narnia, and finally Marija Andraka spoke about Croatian retranslations of Pinocchio.

The following sessions made us choose between music and education, in "The Relationship of Music, Fine Arts, and Other Kinds of Artistic Expressions with Children's Literature" and "New Methodological Approaches in the Interdisciplinary Use of Arts in Children's Literature". I chose music, and heard the Beatles, "Waltzing Matilda", and an enthralling discussion on opera dress codes. Following a delightful lunch (which deserves a paragraph of its own), another two parallel sessions began, this time both mainly focusing on music, theatre, and illustration. The topics included metal lyrics (Eduardo Encabo), the role of music in dystopian narratives (Marit Elise Lyngstad), and a fascinating look at Beatrix Potter's letters (Beatrice Moja). After the sessions there were two workshops (creative writing and poetry), followed by a cocktail hour and a night-time walk.

In Polish, we have a saying that something "went singingly" (poszło śpiewajaco), which means that something went very, very well. Mark Withers' opening keynote of the second day "went singingly" in both the metaphorical and literal sense - by the end, we were all singing multilingual arias of our own creation based on the book Beegu, and a few lucky ones were able to fulfil their lifelong dream of playing the piano. The next two sessions were both titled "The Relationship of Music, Fine Arts and Other Kinds of Artistic Expressions with Children's Literature". I attended the first one, which put together four very different, yet very interesting, topics. First, Ana Catherine Reyes talked about the TALIS programme in the Andes, then Josep Ramon Garcia i Ibáñez discussed introducing political theatre into the classroom (although perhaps likening a surprise performance based on Brecht's Children's Crusade to "attacking the faculty just like Hitler attacked Poland" was a bit unfortunate). After that, Jen Aggleton gave a truly fascinating presentation of her reader-response research and collecting impressions from young readers. The panel ended musically, with Ben Screech's paper on the significance of pop music in young adult novels.

In the next session, I attended the "Fine Art and Picture Book" panel, as I was the final speaker. It was a very interesting session (if I may say so myself), with Rocío Domene Benito talking about Ira's Shakespeare Dream, Farriba Schultz discussing the use of the Imaginarium and creating one's own creature by both young and university students, and Rocío García de Leonardo Gil talking about introducing Julia Donaldson and Axel Scheffler's picturebooks, and a combination of Arts in early-childhood education. Finally, 
my paper discussed the influence of John Tenniel's illustrations on other illustrators of Alice in Wonderland and the use of the strategy of domestication by Olga Siemaszko and Tove Jansson.

After another lunch break accompanied by lively discussions, we had two very inspiring keynotes. First, María Alcantud talked about the TALIS project, and then Macarena García González gave a fascinating and incredibly moving presentation titled "The Arts of Remembering. Transdisciplinary Makings of Cultural Memory for Children", in which she considered the artistic means of introducing children to (hi)stories of national trauma, and talking to them about persecution and dictatorship.

The last two parallel sessions of the day were "Adaptations, Intermediality, Transmediality, Cross-mediality" and "Ekphrasis in Children's Books". This time, I chose the latter. The first speaker was Elżbieta Jamróz-Stolarska who talked about art-inspired picturebook series published by Polish independent publishers. This was followed by IngerKristin Larsen Vie's paper on Norwegian illustrated biographies for children and young adults. Finally, Jessica Medhurst gave a fascinating talk on her time as the Seven Stories' scholar-in-residence and co-curator of the War Horse exhibit.

The final day of the Conference came too soon. It was opened by a keynote by Tzina Kalogirou on ekphrasis in (not-only) poetry. Then there were three parallel sessions during which I tried running between rooms, missing the talks I had planned to go to (especially Smiljana Narančić Kovač's talk on dramatic adaptations of Alice in Wonderland), but finally ending up at two very interesting presentations by Maja Zakrzewska-Pim, who discussed the adaptations of $A$ Christmas Carol, and Karolina Stępien's cognitive analysis of fairytale inspired Polish commercials.

The organisers took great care of us and made us feel quite pampered. Starting with the incomparable Xavier Mínguez-López and his kind pre-conference emails reminding us to pack sunscreen, to the best conference gadget ever, i.e. a very beautiful and practical tote bag which can be rolled into an orange. Also, the coffee breaks were full of local sweet and savoury snacks, excellent coffee and refreshing soft drinks, and the lunches comprised of huge pans of scrumptious paella and many other accompanying treats. During the breaks, we could enjoy live music performed by students, and amuse ourselves with creative, artful entertainment.

The Child and the Book Conference has always enjoyed a great reputation (Naomi Hamer described it as "a conference that claims it's a junior scholar conference, but is attended by everyone"). This year it truly lived up to its outstanding reputation. The atmosphere was very friendly, scholars of all ages and experience shared their thoughts while nibbling on jamón ibérico (Iberian ham). The organisers deserve a hearty thank you and congratulations!

Karolina Rybicka 